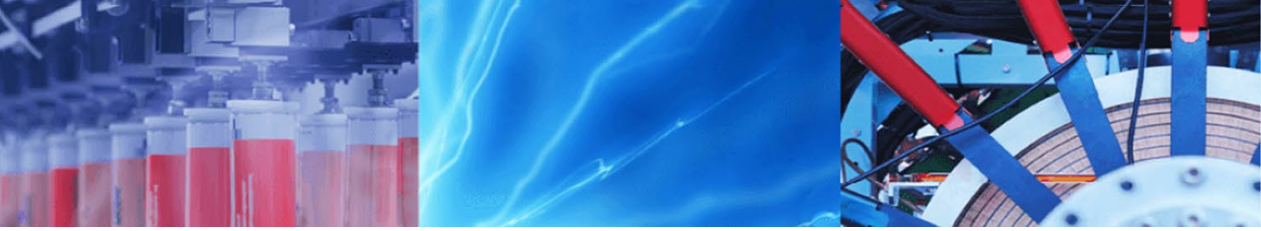

Research Article

\title{
Critical point analysis and biocide treatment in a microbiologically contaminated water purification system of a power plant
}

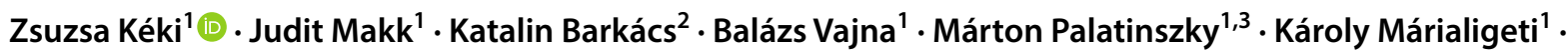 \\ Erika Tóth ${ }^{1}$
}

(c) The Author(s) 2019 OPEN

\begin{abstract}
Many industries use ultrapure water (UPW) for their operation. In spite of purification efforts, microbial contaminations are the major cause of manufacturing problems in these systems. In our experiments, the water purification system of a power plant was investigated: the microbiologically critical points of the ultrapure water purification system were located by checking the number and diversity of bacteria to determine the optimum operational unit for chemical intervention: the most contaminated site was the mixed-bed ion-exchange resin containing unit. Biocides were tested against bacteria previously isolated from the same system; effect of biocides was checked also in laboratory model systems, and based on the results, a biocide treatment was carried out in the mixed-bed ion-exchange resin columns of the working power plant. Kathon WT was the most effective from the studied chemicals, being effective already in low concentration against most studied microorganisms. In case of the handling of the mixed-bed ion-exchange resin, 8-h treatment with $25 \mathrm{ppm}$ biocide concentration was effective. Following the treatment, the quality of the produced UPW met the standards (specific electric conductivity was $<1.0 \times 10^{-3} \mathrm{\mu S} \mathrm{cm}^{-1}$ at $25^{\circ} \mathrm{C}$ ) and water production capacity increased; moreover, the run-down time of the mixed-bed ion-exchange resin significantly grew.
\end{abstract}

Keywords Ultrapure water - Microbial contamination · Power plant · lon-exchange resin · DGGE · Biocide treatment

\section{Introduction}

Many industries (e.g. semiconductor, pharmaceutical, food and beverage industries, power plants) use ultrapure water (UPW) for their operation $[1,2]$. The industrial production of UPW is a complex, multistep process, and the quality of the produced water is extremely important in further use. Unfortunately, all devices and materials (pipelines, tanks, different filters, among them different membranes, ion-exchange resins) provide a large surface area which is favourable for biofilm formation and most of the cells found in the water phase originate also from these biofilms. In many UPW production systems, a variety of methods are involved to remove biofilms and destroy bacteria [3]. In spite of these procedures and the extremely low salt and nutrient concentrations in these habitats, microbial contaminations of these water purification and distribution systems are the major cause of manufacturing problems and process failure [4, 5]. Microbial biofouling and biocorrosion result in reduced lifetime, effectiveness and yield; moreover, it increases operational costs. However, it is impossible to keep a typical industrial system completely sterile; microorganisms on surfaces will always be present $[3,6]$ though their number can be kept on the level of acceptance.

Zsuzsa Kéki, keki.zsuzsa@ttk.elte.hu | ${ }^{1}$ Department of Microbiology, Faculty of Science, Eötvös Loránd University, Pázmány P. stny. 1/C, 1117 Budapest, Hungary. ${ }^{2}$ Department of Chemistry, Faculty of Science, Eötvös Loránd University, Pázmány P. stny. 1/A, 1117 Budapest, Hungary. ${ }^{3}$ Department of Microbiology and Ecosystem Science, Division of Microbial Ecology, University of Vienna, Althanstrasse 14 , 1090 Vienna, Austria.

SN Applied Sciences (2019) 1:820 | https://doi.org/10.1007/s42452-019-0740-9 
In the present study, the water purification system of a power plant was investigated as the run-down processes of the ion-exchange resins were much quicker than under normal cases and also the quality of the produced water was inadequate (specific electric conductivity was $11.2 \mu \mathrm{S} \mathrm{cm}^{-1}$ of the feed water-data provided by the studied power plant). The aim of the present work was to study the microbiological state and to identify the microbiologically critical points of the water purification system in order to determine the optimum operational unit for chemical intervention. Thereafter, biocides were tested against characteristic bacteria previously isolated from the same water supply system, experimental biocide treatment was performed in laboratory model systems, and based on the results biocide treatment was carried out in the water purification/desalination system of the working power plant.

\section{Materials and methods}

\subsection{Sampling}

Sampling was carried out in the feed water production system of a power plant. The structure of the feed water production system investigated with the sampling points is demonstrated in Fig. 1. Water samples were taken via sampling taps into sterilized screw capped flasks. Before sampling, water was allowed to run for $3 \mathrm{~min}\left(6 \mathrm{~L} \mathrm{~min}{ }^{-1}\right)$.

lon-exchange resin samples were collected from the pre-saltless water production ion-exchange unit (three resin columns: organic scavenger-Varion ATM, cationLewatit PC 1800, and anion-Varion ADM, exchange columns) and from a mixed-bed ion-exchange columnPurolite, through the adequate man-holes with sterile scalpels, into sterile plastic screw cap tubes, before and after the regeneration process.

The frequency of the sampling at each sampling point was harmonised with the operational program of the system. Regeneration of anion- and cation-exchange resins happens at each $24 \mathrm{~h}$, in case of mixed-bed ion-exchange resin regeneration of the beads happens usually after 4-5 weeks after starting, depending on the specific electric conductivity of the produced water. At the time of sampling, it was $11.2 \mu \mathrm{S} \mathrm{cm}^{-1}$.

Operational program of the study was as follows; each resin was tested for a whole cycle: backwashing water of the exhausted mixed-bed ion-exchange resin (Fig. 1: 8. point), sampled at 5 different times, once a week for a period of 4 weeks $\left(8 T_{0}-T_{4}\right)$; backwashing water of the freshly installed mixed-bed ion-exchange resin (Fig. 1: 8-2. point) sampled at 6 different times, once a week for a period of 5 weeks $\left(8-2 T_{0}-T_{5}\right)$; product water from the scavenger resin (Fig. 1: 5. point), sampled at 6 different times, once a day for 5 days $\left(5 T_{0}-T_{5}\right)$; product water from the cation-exchange resin (Fig. 1:6. point), sampled at 4 different times, in every $6 \mathrm{~h}$ for $18 \mathrm{~h}\left(6 T_{0}-T_{3}\right)$; product water of the anion-exchange resin (Fig. 1: 7. point) sampling at 4 different times, in every $6 \mathrm{~h}$ for $18 \mathrm{~h}\left(7 T_{0}-T_{3}\right)$.

\subsection{Investigation of the microbial contamination and determination of the critical points of the water purification system}

\subsubsection{Colony forming unit (CFU) and direct cell count determination of the water samples}

The CFU values of the water samples were examined by plating on R2A medium as described by Kéki et al. [7] at the first sampling time from each of the sampling points (1-8).

Direct cell counts were determined from each sample at each sampling time. In case of samples from points $1-2,5,10$ and $25 \mathrm{ml}$, in case of samples from points $3-8$, $200 \mathrm{ml}$ water were fixed with polycarbonate membrane filtered (0.2 $\mu \mathrm{m}$ GTTP, Millipore, USA) 2\% paraformaldehyde (Sigma-Aldrich, Germany) in $0.1 \mathrm{M}$ phosphate buffer $\left(\mathrm{NaH}_{2} \mathrm{PO}_{4} 3.2 \mathrm{~g}, \mathrm{Na}_{2} \mathrm{HPO}_{4} 10.9 \mathrm{~g}\right.$ in $1000 \mathrm{ml}$ distilled water, $\mathrm{pH} 7.2)$ overnight and then filtered $(0.2 \mu \mathrm{m}$ polycarbonate GTTP, Millipore, USA). Filters were stored at $-20^{\circ} \mathrm{C}$ until

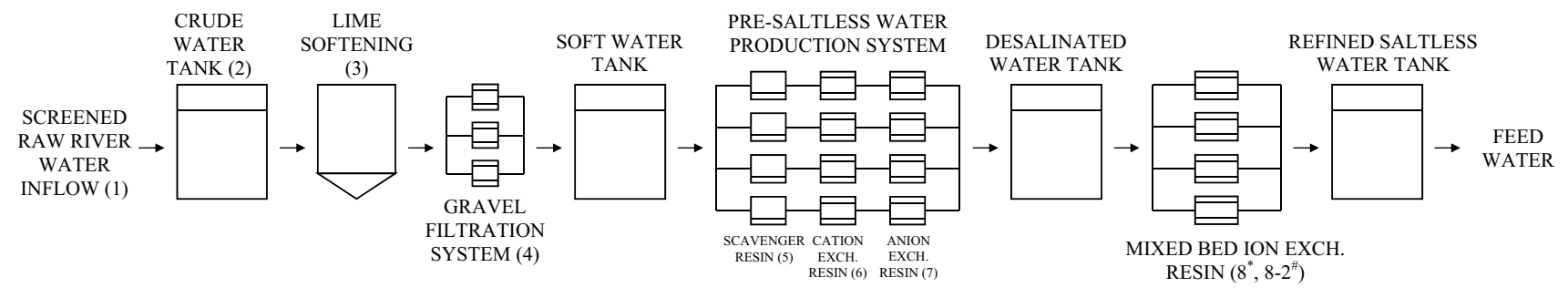

Fig. 1 The structure of the studied water purification and supply system and the sampling points for the critical point analysis. Screened Danube water (1), crude water tank (2), the gravel filtration inlet (3) and outlet (4) water, the scavenger resin outlet water
(5), the product pipes of the cation (6) and anion (7) exchange resin and the mixed-bed ion-exchange unit (8-2), backwashing water of an exhausted mixed-bed ion-exchange unit (8) 
further processing. The membrane filters were then covered with $1 \mu \mathrm{g} \mathrm{mL}^{-1}$ DAPI (4', 6-diamidino-2-phenylindole, Sigma-Aldrich, Germany) solution, and incubated for $2 \mathrm{~min}$ at room temperature. Excess DAPI solution was removed by washing with sterile distilled water and $80 \%$ ethanol (Reanal Ltd., Hungary). Then, the filter was placed in a sterile plastic Petri dish to dry at room temperature. Dried filters were cooled until examination with epifluorescent microscopy (Nikon80i). Photographs were analysed using the ImageProPlus software (Media Cybernetics, Inc., USA).

\subsubsection{Scanning electron microscopy (SEM) of the ion-exchange resin beads}

SEM studies were carried out on all ion-exchange resin beads at the beginning of the critical point analysis. The mixed-bed ion-exchange resin was investigated also at the end of the biocide treatment, and 3 months after the treatment. Resin bead samples were fixed with $5 \%$ glutaraldehyde dissolved in $0.1 \mathrm{M}$ phosphate buffer $(\mathrm{pH} \mathrm{7.2)}$ for $3 \mathrm{~h}$. Thereafter these samples were frozen in liquid nitrogen and freeze-dried until $2 \times 10^{-2} \mathrm{mbar}$ at $-60^{\circ} \mathrm{C}$ for $6-8 \mathrm{~h}$, mounted, coated with gold [8]. Samples were observed in a HITACHI S-2600 N scanning electron microscope at an accelerating voltage of $20 \mathrm{kV}$.

\subsubsection{Molecular analysis}

Microbes were collected from the water samples by filtering $300 \mathrm{~mL}$ aliquot through a sterile $0.45 \mu \mathrm{m}$ pore-size cellulose nitrate membrane filter (Sartorius, Germany). Total DNA extraction from the filters was performed by using Ultra Clean Water DNA Kit (MoBio Laboratories, Qiagen Carlsbad, USA). The DNA samples were stored at $-20^{\circ} \mathrm{C}$ until further processing.

The nearly complete $16 \mathrm{~S}$ rRNA encoding gene fragments were amplified with universal primers $27 F$ ( $5^{\prime}$-AGA GTT TGA TCM TGG CTC AG-3') and 1492R (5'-GGT TAC CTT GTT ACG ACT T-3') using a GeneAmp PCR System 2700 machine (Applied Biosystems, USA). The PCR reactions were performed as described by Nikolausz et al. [9] with the following temperature profile: initial denaturation at $98^{\circ} \mathrm{C}$ for $3 \mathrm{~min}$ followed by 28 cycles of primer annealing at $52{ }^{\circ} \mathrm{C}$ for $30 \mathrm{~s}$, chain extension at $72^{\circ} \mathrm{C}$ for $1 \mathrm{~min}$, denaturation at $95^{\circ} \mathrm{C}$ for $30 \mathrm{~s}$ and a final extension at $72{ }^{\circ} \mathrm{C}$ for $10 \mathrm{~min}$. Amplification was carried out in a GeneAmp PCR System 2700 machine (Applied Biosystems). PCR products were checked by agarose gel electrophoresis.

A second (nested) PCR was performed for the Denaturing Gradient Gel Electrophoresis (DGGE) analysis with 27F (5' AGAGTTTGATCMTGGCTCAG 3') and 319R (5' TGC TCA TGG TGC ACG GTC TA 3 ' with GC clamp) inner primers. $0.5 \mu \mathrm{L}$ template DNA was added to the reaction mixture from the previous PCR product. Other conditions of the $P C R$ reactions were the same as described before. The composition of the polyacrylamide gel, the gradient of denaturants and the conditions of the electrophoresis were carried out according to Felföldi et al. [10]. The gel was stained with ethidium-bromide, washed in sterile double-distilled water, and photographed under UV light.

DGGE molecular fingerprinting was carried out in case of all backwashing water samples originated from the ionexchange units to test the microbial diversity of the resin columns.

Based on the DGGE results, Shannon diversity indices were calculated for the samples; then linear correlation was tested between the diversity indices and direct cell counts using the Past program [11] in case of $T_{0}$ time samples.

\subsection{Biocide treatments}

\subsubsection{Biocide treatment of bacteria isolated from the investigated water purification system}

Sensitivity against biocides was tested in 96-well microplates on 26 selected bacterial strains isolated earlier $[5,7,12]$ from the same water purification system. The applied biocides were Bronopol (Sigma, Germany), ProClin (Supelco, Germany) and Kathon WT (Rohm and Haas, UK) in different concentrations $(0.5 ; 2 ; 5 ; 7.5 ; 10 ; 15 ; 20 ; 50$; $100 ; 150 ; 250 \mathrm{ppm})$. In the test, the $24-48-\mathrm{h}$ slant cultures of the bacteria were suspended in R2A medium [13]; the optical density (OD) values of suspensions were adjusted using the GN and GP standards of BIOLOG system (Biolog Inc., USA). $50 \mu \mathrm{L}$ biocide with the adequate concentration was added to $250 \mu \mathrm{L}$ bacterial suspension into sterile microplates in four replicates and incubated for 7 days at $28{ }^{\circ} \mathrm{C} . \mathrm{OD}_{620}$ of the suspensions was measured daily using a Tecan Sunrise (Tecan Austria $\mathrm{GmbH}$ ) instrument. Data were evaluated using Magellan software v. 3.11. As negative control sterile R2A medium, as positive control $250 \mu \mathrm{L}$ bacterial suspension $+50 \mu \mathrm{L}$ sterile distilled water was used.

Biocide concentrations were accepted as effective only if it killed bacteria, and re-multiplication of the cells was not observed even after 3 days.

\subsection{2 lon-exchange resin biocide treatment in test tubes and in laboratory model system}

Based on the results of sensitivity testing of bacteria, Kathon WT was selected for the laboratory testing of the biocide in the presence of ion-exchange resins. First $2 \mathrm{~mL} \mathrm{5;} \mathrm{7.5;} 10$ and $25 \mathrm{ppm}$ biocide solution was mixed with $1-1 \mathrm{~g}$ of the different resin beads (scavenger, anion, 
cation and mixed-bed ion-exchange resin). The test tubes were rotated for 8, 24 and $72 \mathrm{~h}$ in an overhead mixer (GFL 3025, Lab Unlimited, UK). It was followed by washing three times with $2 \mathrm{~mL}$ UPW of the investigated system (Fig. 1). The $\mathrm{OD}_{620}$ of the washing water was checked as described in 2.3.1 (instead of bacterial suspension $250 \mu \mathrm{L}$ washing fluid was used).

In the next step, a laboratory model system of the ionexchange water treatment was constructed (Fig. 2) which made possible to study the effect of biocide treatment in higher volume before industrial use. The order of the ionexchange units followed the industrial operation (scavenger, anion, cation and mixed-bed ion-exchange resin beads). $500-500 \mathrm{~mL}$ beads (originated from the operational unit of the plant) were put into the $3-L$ size glass sedimentation vessels. The vessels were connected with silicon pipes, and in a closed system UPW of the investigated plant was circulated through the model $\left(3 \mathrm{~L} \mathrm{~min}^{-1}\right)$ for 2 weeks to let biofilm formation happen. Then the water was changed to 25-100 ppm Kathon WT solution to eliminate the microbes. After 8,24 and $72 \mathrm{~h}$, the beads were sampled and washed 3 times with $2 \mathrm{ml}$ UPW; then the $\mathrm{OD}_{620}$ of the washing waters was checked as in 2.3.1 (instead of bacterial suspension $250 \mu \mathrm{L}$ washing fluid was used). Regrowth of bacteria was checked after 24, 48 and $72 \mathrm{~h}$ by controlling $\mathrm{OD}_{620}$.

\subsubsection{On-site application of the biocide}

In the water purification system of the power plant, a mixed-bed ion-exchange resin unit was treated. The treated mixed-bed ion-exchange unit was out of work already for 1.5 years at the time of treatment due to inadequate quality and quantity of the produced water. Treatment steps were as follows: 1 . Sampling the resin beads

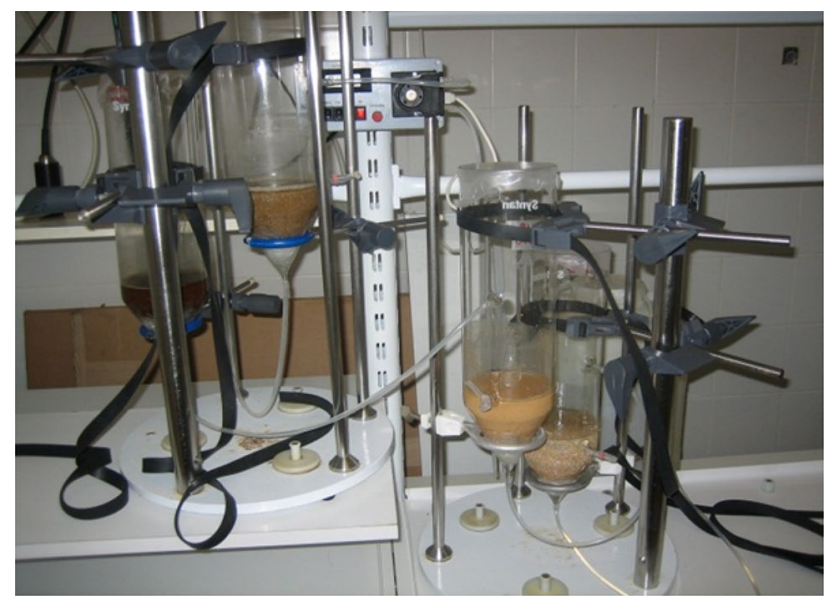

Fig. 2 Experimental laboratory model system for testing biocide treatment with the different resin beads (with sterile scalpel) through the man-hole. 2. Loosening the bed by backwashing operation, and at the end sampling the discharge fluid. 3 . Sampling the resin beads again. 4. Treatment with biocide solution (25 ppm Kathon WT end concentration) for $4 \mathrm{~h}$ (the biocide solution was pumped to the mixed-bed ion-exchange column, and in every hour bed was mixed by aeration). 5 . Biocide solution sluiced into containers and sampled. 6 . Sampling the resin beads again. 7. Sequential rinsing of the mixed-bed ion-exchange column with UPW while the active concentration of Kathon WT in the washing water reached the assigned $0.018 \mathrm{ppm}$ concentration (ecotoxicological standard). 8. Sampling the resin beads again. 9. Regeneration operation of the column by the standard procedures. 10. Sampling the resin beads. 11. Giving back the unit for production again.

\subsection{Ion-exchange capacity analysis}

During the treatments (both experimental, and on-site), the ion-exchange capacity of the resins was tested with static (5.0-5.0 g dried resin bead samples) and with

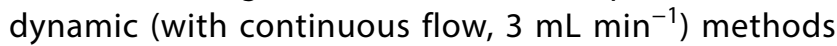
according to the Standard Test Methods [14].

\section{Results}

\subsection{Results of the microbiological investigations and critical point analysis}

\subsubsection{CFU values and direct cell counts}

The aerobic, heterotrophic bacterial plate counting resulted $2-8 \times 10^{4} \mathrm{CFU} \mathrm{\textrm {mL } ^ { - 1 }}$ in the case of the samples from the screened raw river water and the crude water tank (Fig. 1, samples 1 and 2; Fig. 3). In the water leaving the lime softening unit, the CFU values showed two magnitudes lower values (Fig. 1, sample 3). Sample 4 was taken from a gravel filtration system and showed $10^{4} \mathrm{CFU} \mathrm{\textrm {mL } ^ { - 1 }}$ value. CFU values of washing waters of the cation- and anion-exchange resins were low; meanwhile, values of the backwashing water of the mixed-bed ion-exchange resin (Fig. 1, sample 8) were close to that of the river water. Since we wanted to set the CFU values against direct cell counts and regarding to our results direct cell counts showed approximately two magnitudes higher values in case of each samples, and the cell count changes among samples showed similar tendency as the CFU counts (Fig. 3), henceforth only direct cell counts were determined from the further samples. With both methods the backwashing water of the mixed-bed ion-exchange resin showed the highest values. 


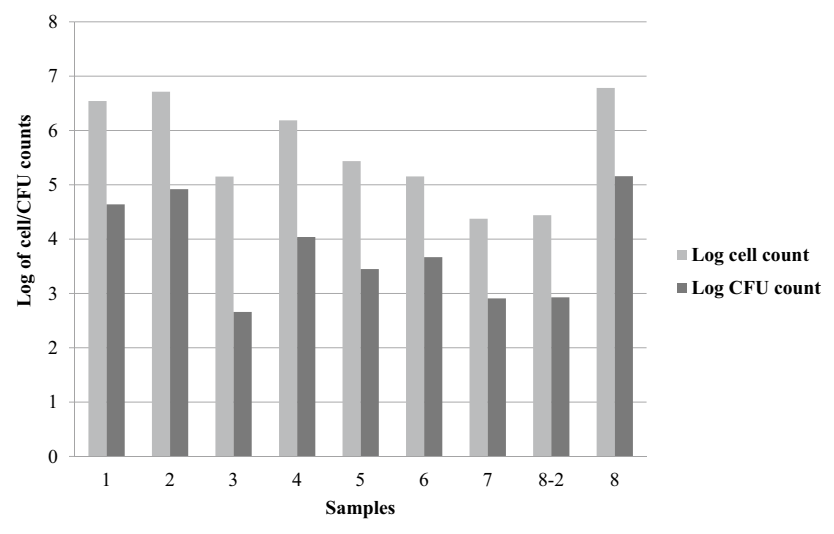

Fig. 3 Log values of the direct cell and CFU counts of the water samples from the examined water purification system. For the origin of samples see Fig. 1

\subsubsection{SEM analysis}

SEM observations showed that all the resin beads of the water purification system were contaminated (Fig. 4): the scavenger ion-exchange resin granules were covered by a remarkable organic and inorganic deposition (Fig. 4a). Anion and cation-exchange resins were cracked (Fig. 4b, c). The cation-exchange resin granules were even partly disintegrated and microbes were detected on their surface. The mixed-bed ion-exchange resin granules were covered by complex biofilm, and growth could be observed between the resin granules, too (Fig. 4d). Within the biofilm, all morphological types of microbes could be observed (coccoid cells, rods and filamentous bacterial forms) (Fig. 4e-f).

\subsubsection{Results of the DGGE analysis}

DGGE analysis has proven the presence of diverse bacterial communities in the backwashing waters. The samples of the different ion-exchange units on the dendrogram grouped together mainly based on the type of the resin, which indicates that the resin columns have different, characteristic microbial communities (Fig. 5). Following the operational program over the time (from $T_{0}$ to $T_{5}$ ), the bacterial community of the freshly installed mixed-bed ion-exchange resin (sample 8-2) became similar to the washing water of the exhausted resin (sample 8-T3).

Backwashing water of the exhausted mixed-bed ionexchange resin, sampled at 5 different times, once a week for 4 week period $\left(8 T_{0}-T_{4}\right)$; backwashing water of the freshly installed mixed-bed ion-exchange resin, sampled at 6 different times, once a week for a 5 week period (8-2 $\left.T_{0}-T_{5}\right)$; product water from the scavenger resin, sampled at 6 different times, once a day for 5 days $\left(5 T_{0}-T_{5}\right)$; product water from the cation-exchange resin, sampled at 4 different times, in every $6 \mathrm{~h}$ for $18 \mathrm{~h}\left(6 T_{0}-T_{3}\right)$; product water of the anion-exchange resin, sampling at 4 different times, in every $6 \mathrm{~h}$ for $18 \mathrm{~h}\left(7 T_{0}-T_{3}\right)$.

The Shannon diversity indices based on DGGE analysis increased with time (Fig. 6) in both the exhausted and newly started mixed-bed ion-exchange resin columns (as compared the results of samples $8{ }_{-} T_{0}$ to $8_{-} T_{4}$ as well as $8-2_{-} T_{0}$ to $8-2_{-} T_{5}$ ). In case of the other resin units similar trend could not be observed (data are not shown).

The direct cell counts of the $T_{0}$ time samples showed significant $(p=0.019)$ linear correlation with the Shannon-Weaver diversity indices: the higher diversity values seemed to represent higher contamination.

\subsection{Biocide treatment}

\subsubsection{Biocide treatment of bacterial strains}

The effect of different biocides against the investigated 26 different bacterial strains is presented in Table 1 .

\subsubsection{Biocide treatment in the laboratory model systems}

In both cases (test tube and model system), the results of the treatment were similar: 8-h treatment time was effective, no bacterial regrowth was observed after this time period. In case of the scavenger resin, the multiplication of the microbes was blocked by both 25 and 100 ppm Kathon WT concentration after $8 \mathrm{~h}$, in the case of the cation and anion ion-exchange resins even the regrowth of microbes could be blocked already by 4 -h treatment with $25 \mathrm{ppm}$ biocide concentration. The results of the 8 -h treatment of the mixed-bed ion-exchange resin are presented in Fig. 7.

It is clear from Fig. 7 that only washing the resin with UPW (before the indicated biocide treatment) did not result the complete elimination of microbes from the bead surfaces, since the optical density (bacterial biomass in the washing water) values were high and barely changed, though their number decreased. Moreover, regrowth of bacteria always could be observed. However, the applied $25 \mathrm{ppm}$ Kathon WT (the time of the treatment is indicated by arrow) killed most of the microbes and regrowth was not observed (optical density values decreased significantly) neither after $72 \mathrm{~h}$.

\subsubsection{On-site biocide treatment}

Based on the laboratory model system studies, it was obvious that the treatment of the mixed-bed ion-exchange resin was sufficient to eliminate most microbes. Therefore, biocide treatment of the mixed-bed ion-exchange resin was decided to solve the microbial contamination problem in the power plant on site. 


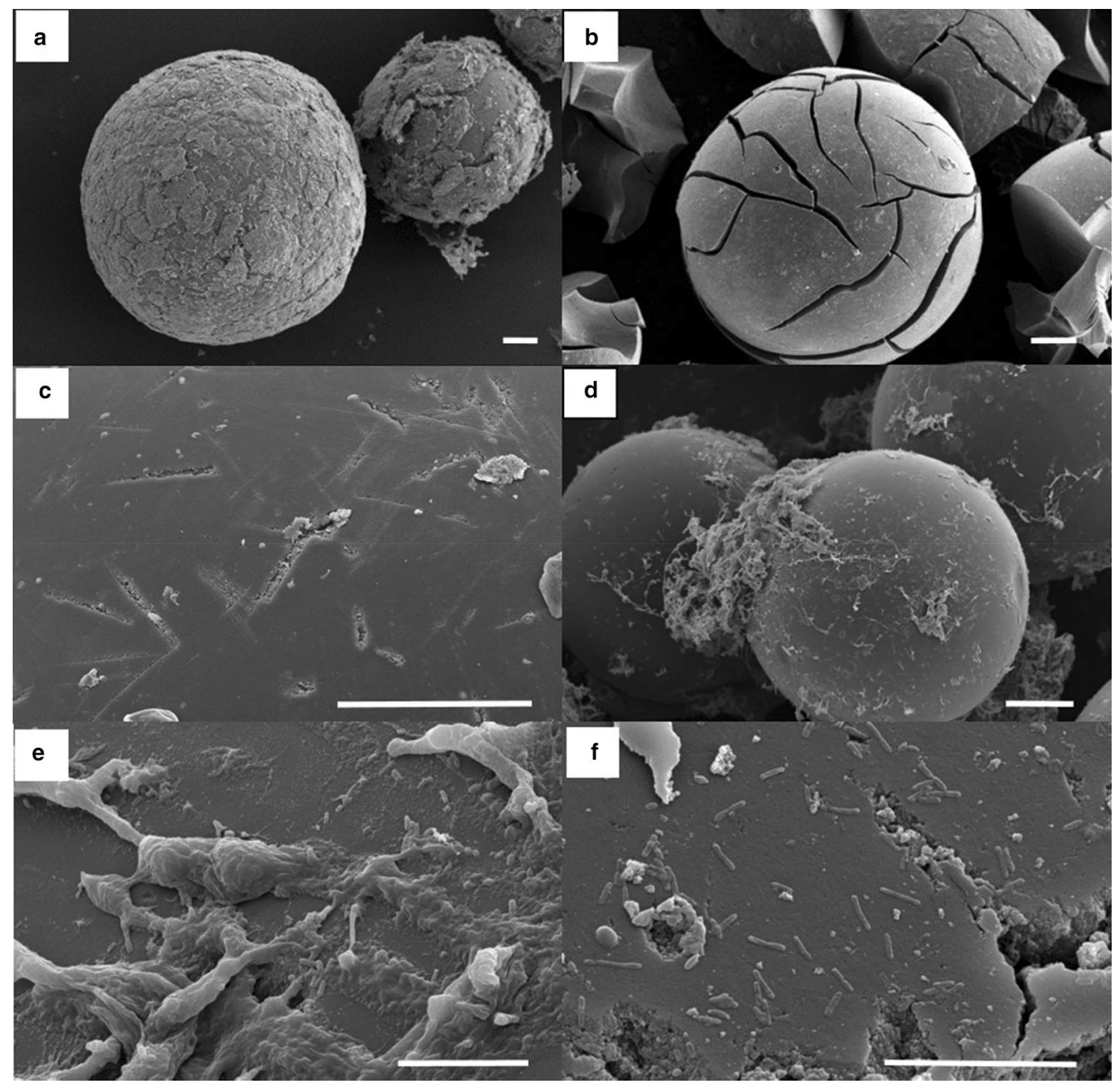

Fig. 4 SEM photographs of the ion-exchange resin beads before biocide treatment (scale bar $=100 \mu \mathrm{m})$. a scavenger resin bead (Varion ATM) with organic and inorganic surface deposit; b cationexchange resin beads (Lewatit PC 1800) with deep ruptures; c sur- face of the anion-exchange resin beads (Varion ADM); $\mathbf{d}$ mixed-bed ion-exchange resin beads (Purolite) covered by microbial biofilm; e and $\mathbf{f}$ after loosening backwashing, before biocide treatment
The results after the on-site treatment of the mixed-bed ion-exchange resin unit showed that biocide treatment was sufficient (Fig. 8a, b); microbes were visibly eliminated from the bead surfaces.

Three months after the biocide treatment, the bacterial contamination of the resin was checked again. From SEM photographs, it was obvious that microbial colonization has started again (Fig. 9).

\subsection{Results of the ion-exchange capacity investigations}

Results of the ion-exchange capacity studies showed that after the biocide treatment the capacity was at least $10 \%$ higher in case of scavenger (Varion ATM) and anion exchange (Varion ADM and Purolite-A500TL) than before treatment, at the same time ion-exchange capacity of 
Fig. 5 Results of DGGE analysis, bacterial community of the water samples

Fig. 6 Changes of the Shannon diversity indices based on the DGGE analysis in case of the backwashing water samples of the mixed-bed ionexchange unit. 8: exhausted ion-exchange resin. 8-2: newly started ion-exchange resin
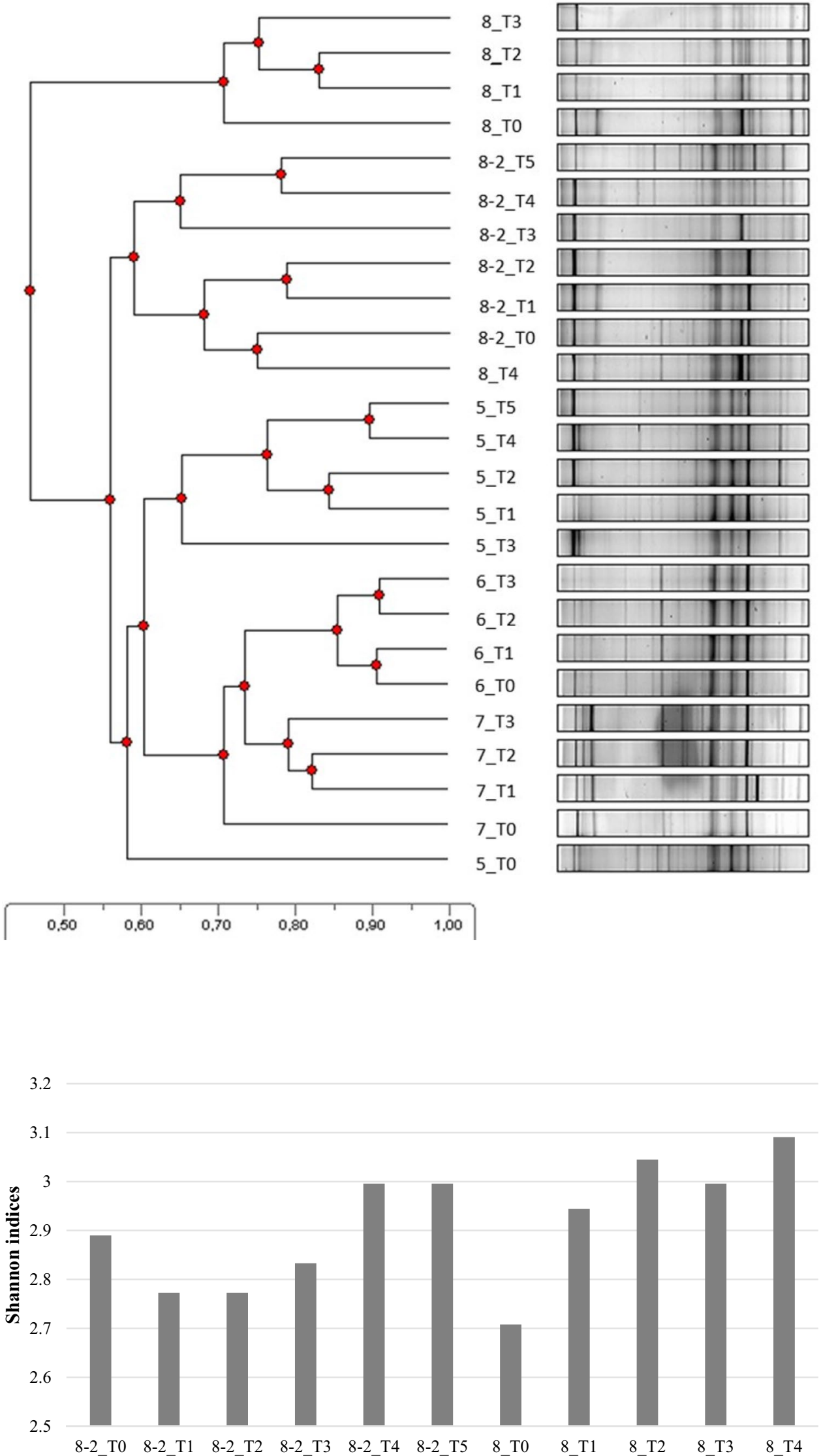

Samples (backwashing water of mixed-bed ionexchanged resin) 
Table 1 Bacteria originating from the investigated ultrapure water system and their sensitivity against different biocides
Fig. 7 Results of 8 h 25 ppm Kathon WT treatment of the mixed-bed ion-exchange resin in the laboratory model system. Arrow indicates the time of the biocide treatment. Before and after the biocide handling washing with $2 \mathrm{ml}$ UPW was applied (0 W: no washing, $1 \times \mathrm{W}$ : single washing, $2 \times \mathrm{W}$ : double washing, $3 \times \mathrm{W}$ : triple washing). The optical density indicates the bacterial biomass in the washing water

\begin{tabular}{|c|c|c|c|c|}
\hline \multirow[t]{2}{*}{ Strain ID } & \multirow[t]{2}{*}{ The identified bacterial species } & \multicolumn{3}{|c|}{$\begin{array}{l}\text { The smallest effective concentration of the } \\
\text { applied biocides (ppm) }\end{array}$} \\
\hline & & Bronopol & ProClin & Kathon WT \\
\hline BBT46 & Mycobacterium fluoranthenivorans & 250 & 250 & NE \\
\hline BB5BC & Mycobacterium fluoranthenivorans & NE & 5 & NE \\
\hline BB1B & Rhizobium rhizogenes & 100 & 15 & 7.5 \\
\hline BBM14A & Rhizobium lusitanum & 50 & 15 & NE \\
\hline BBM23B & Ralstonia insidiosa & 50 & 5 & 5 \\
\hline BBM44A & Rhodococcus erythropolis & 150 & 15 & 7.5 \\
\hline BBM39 & Bradyrhizobium denitrificans & 50 & 5 & 5 \\
\hline BBT51 & Brevibacterium casei & 50 & 15 & 20 \\
\hline BBT67B & Micrococcus terreus & 50 & 15 & 10 \\
\hline BB6A & Bacillus mycoides & 15 & 2 & 5 \\
\hline FII-6 & Mycobacterium aubagnense & NE & 5 & 5 \\
\hline FII-4 & Methylobacterium oryzae & 50 & 5 & 5 \\
\hline FII-38 & Paenibacillus provencensis & NE & 5 & 5 \\
\hline FII-1 & Labrys miyagiensis & 50 & 5 & 5 \\
\hline FII-8 & Burkholderia stabilis & 50 & 5 & 5 \\
\hline FII-15 & Mesorhizobium camelthorni & 50 & 15 & 10 \\
\hline FII-29 & Mesorhizobium australicum & 50 & 15 & 10 \\
\hline FIII-22b & Leifsonia shinshuensis & 50 & 15 & 20 \\
\hline FIII-24 & Leifsonia shinshuensis & 50 & 50 & 20 \\
\hline PS-1 & Porphyrobacter donghaensis & 15 & 0.5 & 1 \\
\hline PI-18 & Sphingomonas azotifigens & 50 & 5 & 7.5 \\
\hline PI-35 & Rhizobium taibaishanense & 50 & 5 & 7.5 \\
\hline PII-4 & Ancylobacter polymorphus & 100 & 50 & 5 \\
\hline PIII-13 & Mycobacterium chlorophenolicum & $\mathrm{NE}$ & NE & 5 \\
\hline PIII-40 & Pelomonas puraquae & 15 & 5 & 5 \\
\hline PIII-41 & Microbacterium luteolum & 50 & 50 & 20 \\
\hline
\end{tabular}

$N E$ not effective in the tested concentrations

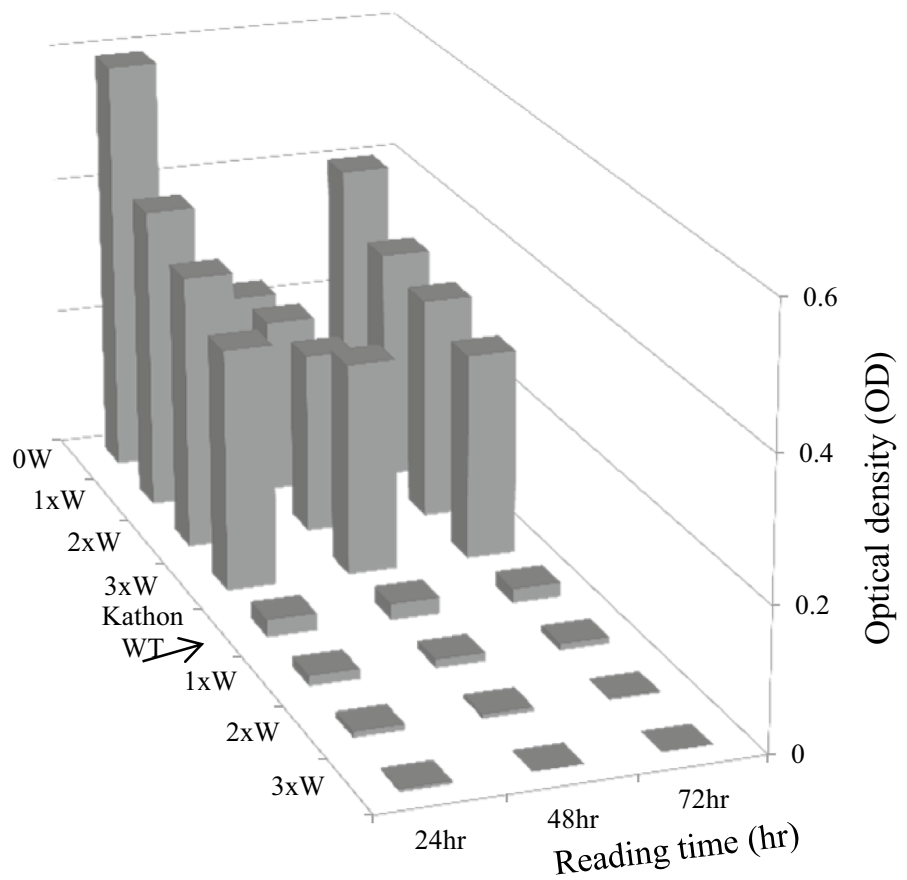




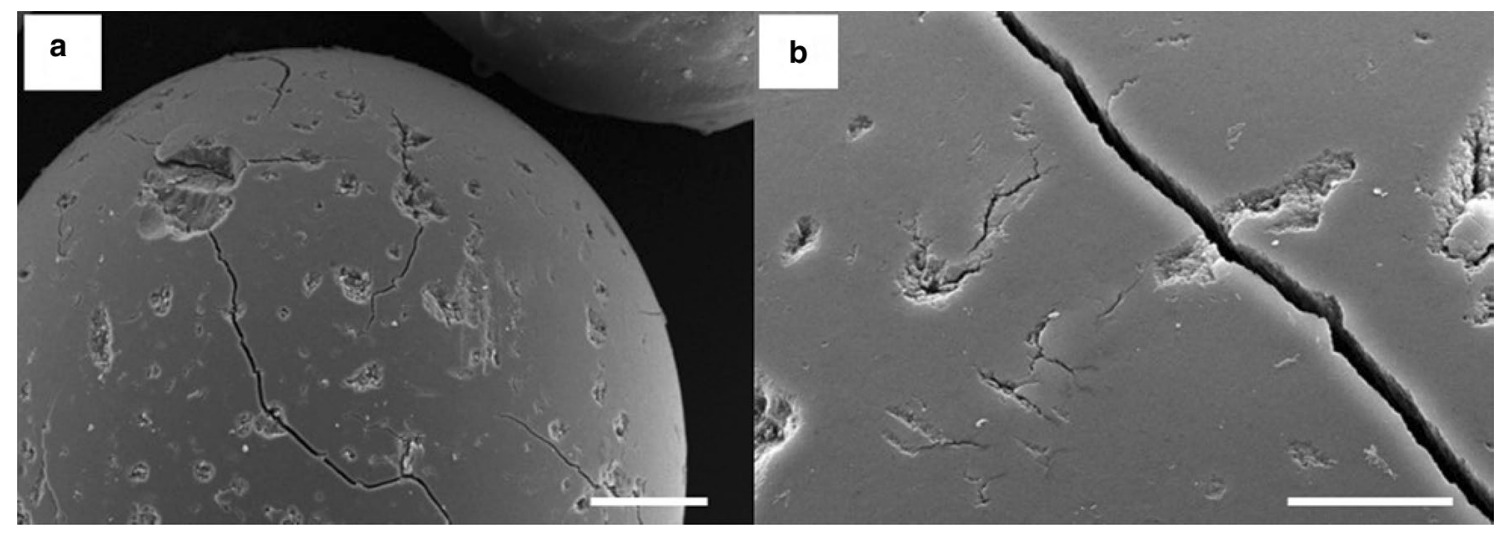

Fig. 8 SEM images of mixed-bed ion-exchange resin. a, b After 25 ppm Kathon WT treatment for 8 h (a: scale bar $=100 \mu m),(\mathbf{b}: s c a l e$ $\operatorname{bar}=20 \mu \mathrm{m})$

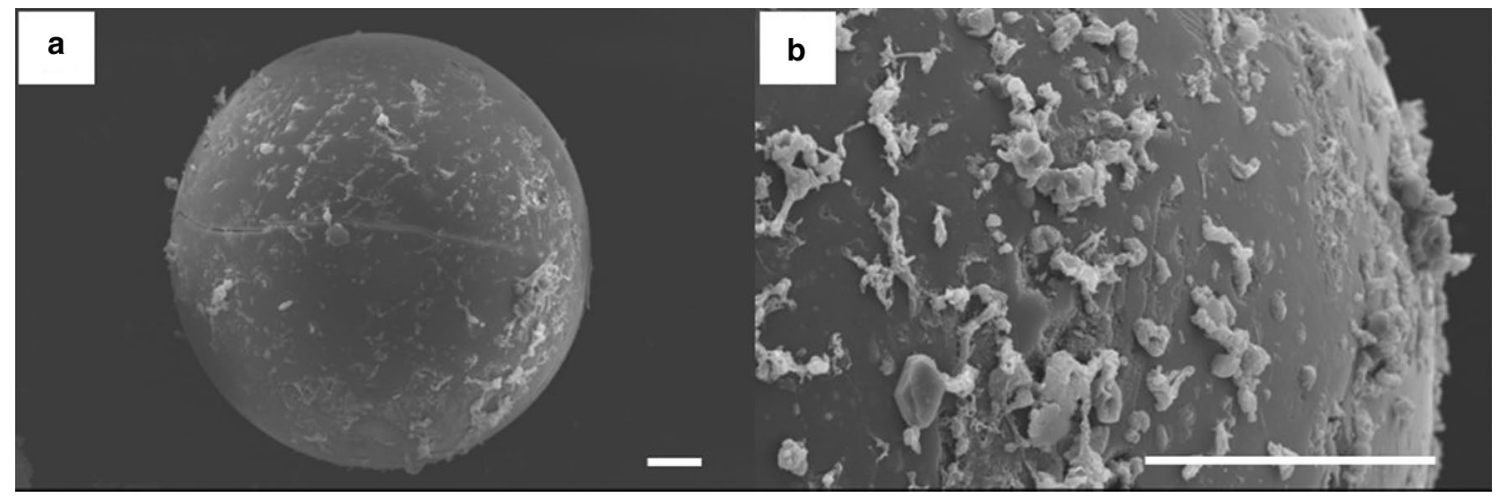

Fig. 9 The surface of the mixed-bed ion-exchange resin beads. $\mathbf{a}, \mathbf{b} 3$ months after the treatment (scale bar $=100 \mu \mathrm{m})$

cation-exchange resins (Varion KS and Purolite-C150TLH+) didn't change significantly.

\section{Discussion}

Microbial contamination of pure waters (including UPWs) is known for decades [4, 15-17]. In 1995 Mittelman [18] described microbiological infection of microelectronic devices and membrane filters connected to the applied UPW. During the last decades, the manufacturers have realised the importance of water purity and its effect on the quality of the final product as well as on the purification system itself. A system that provides purified water (especially that of UPW) has to meet many standards stable for prolonged time; therefore, they must be protected also from microbial proliferation. Bacterial contamination of ultrapure waters, even if organic and inorganic chemical pollutants are removed to meet the prescribed standard values, can cause several manufacturing problems [19] as bacteria often can use the materials of the pipes or other parts of the system as nutrient or reducing power source. Matsuda et al. [20] studied the microbial contamination of UPWs, where they used mixed-bed ion-exchange resin exactly to eliminate microbes. On contrary to our results, microbes did not multiply there on the surface of the tested ion-exchange resins.

Kulakov et al. [3] examined microbial contamination of UPW of a water purification system with cultivation and cultivation independent methods. They observed also that direct cell counts measured by epifluorescent microscopy are at least 1-2 magnitude higher than CFU values independently of the applied cultivation media. They could not demonstrate significant differences at the different points of the studied systems in the number of bacteria. In our case, obvious disparities could be detected at the different points of the water purification system (Figs. 3 and 4). The lime softening showed strong reducing effect on the bacterial cell counts. Significant decrease could be observed in the number of bacteria also at the anion-exchange resin (Fig. 3) most probably due to the frequent regeneration process carried out by $\mathrm{cc}$. $\mathrm{NaOH}$, 
thus destroying many microbial cells as was demonstrated also by Seale et al. [21]. At the same time, Abdelsalam et al. [22] observed strong bacterial contamination on the surface of anion-exchange resin beads when the fouling of an electric power plant was studied. In their experiments, most observed bacteria belonged to the genus Bacillus which can survive treatments with their endospores. To avoid microbial contamination of these waters, several methods exist, Husted and Rutkowski [23] stated that already a hot water washing is sufficient for elimination of microbes from the surface of the resin beads. Ozonisation can kill microorganisms, but disinfecting the water requires maintaining a certain dissolved ozone concentration for a given contact time; thus, its efficiency depends on the ozone residual concentration and also that of the quantity of target microorganisms [24, 25]. UV radiation can be used to kill microorganisms by denaturing their DNA [26], but even so the complete elimination of bacteria from a water purification system is impossible. Moreover, during environmental monitoring an institution's watering system Molk et al. [27] observed that the often used reverse-osmosis membranes had high bacterial loads in their automatic water system.

In our case, the most contaminated site of the studied water purification system was obviously the mixed-bed ion-exchange unit (based on the experienced CFU values and cell counts as well as SEM studies). The cell count of backwashing water of this resin showed also that microbes on the surface of the resin beads were strongly attached to it. As shown in Fig. 7, in laboratory circumstances washing only is not adequate to eliminate microbes and to solve the problem.

DGGE results also showed that microbial contamination has occurred at each sampling points and diverse communities could be observed-though it is important to state that our methods indicate also the DNA of the dead cells. The water samples originating from the different ionexchange resin columns grouped together mainly based on the type of the resin, which indicates that each resin unit has different, characteristic microbial communities. It seems that the bacterial communities of the different ion-exchange resin columns are much more influenced by the physical and chemical characters than that of the run-down process of the given resin. In agreement with our DGGE studies, Kulakov et al. [3] observed that the composition of the microbial communities of the different points of the water purification system differ strongly. Most probably the structure of a water purification system and the applied materials in its structure strongly influence the development of microbial communities [19, 28, 29].

In our experiments, biocides were used to decrease the number of bacteria in the studied purification system. It is known that many biocides kill most algae and bacteria without strongly offending the environmental components [30]; therefore, we have selected isothiazolone derivatives (ProClin and Kathon WT) and Bronopol. These biocides are often used as antimicrobial compounds in cosmetic and textile industries and in water supply systems [31,32]. These chemicals quickly block the multiplication of microorganisms with irreversible harms causing cell death: they destroy the structure of many proteins by creating disulphide bonds in them. Moreover, when a given biocide contacts the microbe, free radicals may be generated which are toxic for the cells. In our experiments most bacteria were sensitive for the tested biocides already in low concentrations (Table 1.). Though it is well known from literature that microbes in biofilms can tolerate much higher biocide concentrations than in pure cultures [33, 34]. Therefore, when the aim is to eliminate microbes living in biofilms, higher biocide concentrations must be applied than for pure cultures.

Our results showed that Mycobacterium species were the most resistant to two applied biocides (Bronopol and ProClin). On the other hand, Kathon WT was the most effective from the studied chemicals already in low concentrations (1-20 ppm) against most tested bacteria; therefore, in later studies and industrial treatment this biocide was used (Table 1.). Mycobacerium species were exception, but it is not surprising. Already early studies revealed that mycobacteria were more resistant to biocides than other non-sporulating bacteria $[35,36]$. Usually the components of the mycobacterial cell wall are responsible for high biocidal resistance [37].

It is worth to mention that against antimicrobial compounds (also against biocides) often resistance mechanisms develop in microbes-therefore, it is impossible to eliminate all microbes with the same chemical compound at the same time [33]. In case of the mixed-bed ion-exchange resin the 8-h-long treatment with $25 \mathrm{ppm}$ biocide concentration was effective to block the regrowth of bacteria in spite that the resin beads surfaces were strongly contaminated before the treatment. The on-site purification of the resin beads was possible with this biocide concentration though a high speed reverse flow was also necessary to remove the dead cells from the bead surfaces: physical treatment (e.g. backwash) together with chemical treatment was really effective to eliminate microbes (Fig. 8).

Just after the treatment the quality of produced UPW met the standards (specific electric conductivity

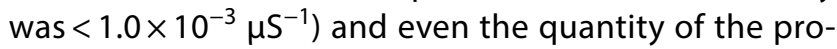
duced water was much higher, the run-down of the mixedbed ion-exchange resin lasted longer than before. So it is obvious that biocide treatment had positive effect on the ion-exchange capacity and effectiveness of water 
purification by elimination of microorganisms even if the ion-exchange capacity has grown only moderately.

On the other hand, after 3-month operation, recolonization by microbial cells could be observed. In general, it cannot be expected that a single biocide treatment can solve the problem finally as the applied water itself is not sterile. The measured ion-exchange capacity was lower after the treatment in case of cation-exchange resin but higher in case of the other resins, most probably significant amount of contamination was removed by the treatment.

\section{Conclusions}

Our experiments showed that biocide treatment with Kathon WT in the water purification system in the power plant was successful, effective against microbial contamination. Based on our results, we have suggested to wash the mixed-bed ion-exchange resin each month with an intensive, opposite flow saltless water and apply biocide treatment in every 3 months to avoid strong microbial proliferation and to keep the good quality of the supplied water. We are convinced that this study provides a solid basis for guiding the authorities and technical engineers to decrease the microbial contamination in industrial ultrapure waters.

Acknowledgements Open access funding provided by Eötvös Loránd University (ELTE).

Funding This study was supported by the Ministry of Human Capacities and by the ELTE Institutional Excellence Program (1783-3/2018/ FEKUTSRAT) given by the Hungarian Ministry of Human Capacities.

\section{Compliance with ethical standards}

Conflict of interest This manuscript has not been published and is not under consideration for publication elsewhere. We have no conflicts of interest to disclose. On behalf of all authors, the corresponding author states that there is no conflict of interest.

Open Access This article is distributed under the terms of the Creative Commons Attribution 4.0 International License (http://creativeco mmons.org/licenses/by/4.0/), which permits unrestricted use, distribution, and reproduction in any medium, provided you give appropriate credit to the original author(s) and the source, provide a link to the Creative Commons license, and indicate if changes were made.

\section{References}

1. ASTM D5127-13 (2013) Standard guide for ultra-pure water used in the electronics and semiconductor industries. ASTM International, West Conshohocken
2. Satpathy KK, Mohanty AK, Sahu G, Biswas S, Selvanayagam M (2010) Biofouling and its control in seawater cooled power plant cooling water system - a review. Nucl Power 11:191-243

3. Kulakov LA, McAlister MB, Ogden KL, Larkin MJ, O'Hanlon JF (2002) Analysis of bacteria contaminating ultrapure water in industrial systems. Appl Environ Microbiol 68:1548-1555

4. Governal R, Bonner A, Shadman F (1991) Effect of component interactions on the removal of organic impurities inultrapure water systems. Trans Semicond Manuf 4:298-303

5. Bohus V, Tóth EM, Székely AJ, Makk J, Baranyi K, Patek G, Schunk J, Márialigeti K (2010) Microbiological investigation of an industrial ultra pure supply water plant using cultivation-based and cultivation-independent methods. Water Res 44:6124-6132

6. Cristiani $P$ (2005) Solutions to fouling in power station condensers. Appl Therm Eng 25:2630-2640

7. Zs K, Grébner K, Bohus V, Márialigeti K, Tóth EM (2013) Application of special oligotrophic media for cultivation of bacterial communities originated from ultrapure water. Acta Microbiol et Immunol Hung 60:345-357

8. Makk J, Ács É (1996) Interaction between diatoms and bacteria in the biofilm of the Danube river. In: Proceedings of the 31st international conference of IAD, IAD Wien, pp 109-114

9. Nikolausz M, Márialigeti K, Kovács G (2004) Comparison of RNAand DNA-based species diversity investigations in rhizoplane bacteriology with respect to chloroplast sequence exclusion. J Microbiol Methods 56(3):365-373

10. Felföldi T, Somogyi B, Márialigeti K, Vörös L (2009) Characterization of photoautotrophic picoplankton assemblages in turbid, alkaline lakes of the Carpathian Basin (Central Europe). J Limnol 68:385-395

11. Hammer O, Harper DAT, Ryan PD (2001) PAST: paleontological statistics software package for education and data analysis. Palaeontol Electronica 4(1):9

12. Bohus V, Zs K, Márialigeti K, Baranyi K, Patek G, Schunk J, Tóth EM (2011) Bacterial communities in an ultrapure water containing storage tank of a Hungarian power plant. Acta Microbiol et Immunologica Hung 58(4):371-382

13. Reasoner DJ, Geldreich EE (1985) A new medium for the enumeration and subculture of bacteria from potable water. Appl Environ Microbiol 49:1-7

14. ASTM Standard C33 (2003) Specification for concrete aggregates. ASTM International, West Conshohocken

15. Characklis WG (1981) Bioengineering report: fouling biofilm development-a process analysis. Biotechnol Bioeng 23:1923-1960

16. Gough A (1986) Microbial contamination in ultra-pure water. Solid State Technol 29:139-142

17. Patterson MK, Husted GR, Rutkowski A, Mayette DC (1991) Isolation, identification and microscopic properties of biofilms in high-purity water distribution systems. Ultrapure Water 8:18-23

18. Mittelman MW (1995) Biofilm development in purified water systems. In: Lappin-Scott HM, Costerton J (eds) Microbial biofilms. Cambridge University Press, Cambridge, pp 133-144

19. Rao TS, Nair KVK (1998) Microbiologically influenced stress corrosion cracking failure of admiralty brass condenser tubes in a nuclear power plant cooled by freshwater. Corros Sci 40:1821-1836

20. Matsuda N, Agui W, Tougou T, Sakai H, Ogino K, Abe M (1996) Gram-negative bacteria viable in ultrapure water: identification of bacteria isolated from ultrapure water and effect of temperature on their behavior. Colloids Surf B Biointerfaces 5:279-289

21. Seale RB, Bremer PJ, Flint SH, McMillan AJ (2011) Characterization of spore surfaces from a Geobacillus sp. isolate by $\mathrm{pH}$ dependence of surface charge and infrared spectra. Appl Microbiol 52(2):104-108 
22. Abdelsalam SM, Kheiralla ZMH, Aboseif FA, Asker SME (2017) Abiotic factors and microbial communities fouling anion exchange resin causing performance deficiency in electric power plants. Egypt J Microbiol 52:17-28

23. Husted G, Rutkowski A (1991) Control of microorganisms in mixed bed resin polishers by thermal sanitization. Proc Watertech: 43-51

24. Summerfelt ST, Hochheimer JN (1997) Review of ozone processes and applications as an oxidizing agent in aquaculture. Progress Fish Cult 59:94-105

25. Liltved $\mathrm{H}$ (2001) Ozonation and UV-irradiation. In:Timmons MB, Ebeling JM, Wheaton FW, Summerfelt ST, Vinci BJ (eds) Recirculating aquaculture systems, chap 12. Northeast Regional Aquaculture Center, North Dartmouth, pp 351-382

26. Rodriguez J, Gagnon S (1991) Disinfection: liquid purification by UV radiation, and its many applications. Ultrapure Water 8(6):26-31

27. Molk DM, Karr-May CL, Trang ED, Sanders GE (2013) Sanitization of an automatic reverse-osmosis watering system: removal of a clinically significant biofilm. J Am Assoc Lab Anim Sci 52(2):197-205

28. Chen $\mathrm{CL}$, Liu WT, Chong ML, Wong MT, Ong SL, Sean $\mathrm{H}, \mathrm{Ng}$ WJ (2004) Community structure of microbial biofilms associated with membrane-based water purification processes as revealed using a polyphasic approach. Appl Microbiol Biotechnol 63:466-473

29. Penna VTC, Martins SAM, Mazzola PG (2002) Identification of bacteria in drinking and purified water during the monitoring of a typical water purification system. BMC Public Health 2:13-21
30. Gregg MD, Hallegraeff GM (2007) Efficacy of three commercially available ballast water biocides against vegetative microalgae, dinoflagellate cysts and bacteria. Harmful Algae 6(4):567-584

31. Williams TM (2007) The mechanism of action of isothiazolone biocides. Power Plant Chem 9:14-22

32. Laopaiboon L, Smith RN, Hall SJ (2001) A study of the effect of isothiazolones on the performance and characteristics of a laboratory-scale rotating biological contactor. J Appl Microbiol 91:93-103

33. Cloete TE, Brözel VS, Von Holy A (1992) Practical aspects of biofouling control in industrial water systems. Int Biodeterior Biodegrad 29:299-341

34. Cloete TE, Jacobs L, Brözel VS (1998) The chemical control of biofouling in industrial water systems. Biodegradation 9:23-37

35. Croshaw R (1971) The destruction of mycobacteria. In: Hugo WB (ed) Inhibition and destruction of the microbial cell. Academic Press, London, pp 42-49

36. Russell AD (1996) Activity of biocides against mycobacteria. J Appl Bacteriol 81:87-101

37. Le Dantec C, Duguet JP, Montiel A, Dumoutier N, Dubrou S, Vincent V (2002) Chlorine disinfection of atypical mycobacteria isolated from a water distribution system. Appl Environ Microbiol 68:1025-1032

Publisher's Note Springer Nature remains neutral with regard to jurisdictional claims in published maps and institutional affiliations. 